\title{
Interpolation of rainfall through polynomial regression in the Marche Region (Central Italy)
}

\author{
Matteo GENTILUCCI ${ }^{1}$, Carlo BISCI ${ }^{1}$, Peter BURT ${ }^{2}$, Massimilano \\ FAZZINI ${ }^{1}$, Carmela VACCARO ${ }^{3}$
}

${ }^{1}$ School of Sciences and Technologies, University of Camerino, Camerino, Italy

${ }^{2}$ Department of Agriculture, Health and Environment, Natural Resources Institute, University of Greenwich at Medway, Chatham, Kent, ME4 4TB, UK

${ }^{3}$ Department of Physics and Earth Sciences, University of Ferrara, Ferrara, Italy

Dr. Matteo Gentilucci - +393474100295 - matteo.gentilucci@unicam.it - V.le

Indipendenza, 180 - 62100 Macerata - Correspondingauthor

Prof. Carlo Bisci - carlo.bisci@unicam.it

Dr Peter Burt - p.j.a.burt@greenwich.ac.uk

Dr. Massimiliano Fazzini- fzzmsm@unife.it

Prof. Carmela Vaccaro - vcr@unife.it

\begin{abstract}
Notwithstanding its small size (less than $10000 \mathrm{~km}^{2}$ ), because of its varied topography, ranging from the Apennines Range (up to more than $2000 \mathrm{~m}$ amsl) to coastal environments, the Marche Region (the Adriatic side of Central Italy), is characterized by many different types of climate.

In this region there are no fully satisfactory models to interpolate and generalize rainfall data from the 11 lavailable meteorological recording stations; however, in this study an innovative way to interpret data linking precipitation to many topographic parameters is introduced.

Based on those considerations, statistical analyses were carried out on rainfall historical series in order to assess significantly variations during the last 60 years and to create a model capable of explaining rainfall distribution based on geographical and topographic parameters. Thus on one hand was highlighted a significant decrease of rainfall from 1961-1990 to 1991-2016, over the whole period, in the hilly and mountainous sectors $(100-200 \mathrm{~mm})$, while closer to the coast the difference is slight (about $0-100 \mathrm{~mm}$ ), on the other the new model highlights the presence of some outliers, which may lead to a better comprehension of climatic dynamics in this area
\end{abstract}

Keywords: Rainfall, Marche Region, Multiple Regressions, GIS, Climate 


\section{Introduction}

\subsection{Aim of the study}

The Marche Region has various environments and climate types that influence precipitation. The present study about precipitation of Marche Region was performed in a period from 1961 to 2016, divided into two sub-periods of 30 years, in order to make it comparable with other climate analysis in the rest of the world, following the protocol of the World Meteorological Organization.

This research has two aims:

- to investigate the spatial distribution of precipitation variations in the Marche Region from 1961-1990, in order to assess possible climate change in the last period 1991-2016;

- to assess how local precipitation is correlated with geographical and topographic parameters, in order to develop a predictive computer program for the creation of an acceptable mathematical model of prediction.

\subsection{Geography of the area}

Since systematic statistical analyses of the influence of geographical and topographic features on precipitation are lacking for the Marche Region (Fig. 1), data recorded by more than 100 rain gauges in the Marche Region and in its neighbours (Emilia Romagna, Tuscany and Lazio, Figure 1) have been analyzed.

The study area stretches over $10,000 \mathrm{~km}^{2}$ and is located on the Adriatic side of Central Italy. With the exception of a small sub-basin draining to the Tyrrhenian Sea (the Nera River sub-basin of the Tiber River), the Region is characterized by elevations progressively decreasing eastwards (from the Apennines to the Adriatic Sea). Within the Region, all rivers follow the regional altitudinal gradient, flowing almost perpendicularly to the coastline. No lakes are present, even though there are many reservoirs of different size. The area is mostly hilly (ca. 69\%) and subordinately mountainous (ca. 31\%, to the west): the maximum elevation is Mt Vettore (2476 m a.s.1.), located at the Region's SW boundary. Alluvial plains are small and narrow. There are four main climate types [Köppen, 1900; Geiger, 1954; Spina et al., 2002] in Marche Region:

- Cfa - temperate climate with sufficient rainfall in all months and the hottest month above $22{ }^{\circ} \mathrm{C}$; it is present up to $30-40 \mathrm{~km}$ inland from the coast; 
- $\mathrm{Cfb}$ - temperate climate with sufficient rainfall in all months and the average of the hottest month colder than $22^{\circ} \mathrm{C}$; it is typical of altitudes approximately ranging between $500 \mathrm{~m}$ and $1000 \mathrm{~m}$;

- Cfsbx" - climate similar to the previous one, but with less than 4 months with average temperature higher than $10{ }^{\circ} \mathrm{C}$, it is present from $1200 \mathrm{~m}$ to $1800 \mathrm{~m}$, where there are no dry periods, the highest monthly amount of precipitation is in the cold season (fs), with a peak in the autumn-winter and a secondary maximum in spring ( $\mathrm{x}$ "), and

- Dfsbx" - snow-forest climate with an average temperature lower than $3^{\circ} \mathrm{C}$ in the coldest month; it is present only above $1800 \mathrm{~m}$; the precipitation regime is identical to that of Cfsbx" climate type, but during the three winter months on the highest peaks the nivometric ratio reaches $90 \%$.

Furthermore it is important also to consider air masses. Italy is affected by 8 air masses, however only 4 of these have a considerable influence for the Marche Region, because of its topography:

1. Continental Arctic cold. This originates from North Russia, above all Siberia and it can affect Italy from the end of October to April. This is the coolest air which may involve the Italian nation;

2. Continental Polar cold. Cold and dry air originating from southern Russia, which arrives over Italy from the Balkan area;

3. Continental Tropical warm. Hot and very dry air originating from arid and desert areas, its source is from south. It is the hottest air mass which affects Italy.

4. Maritime Tropical warm. This kind of air mass originating from the South-West (in the Atlantic Ocean near Azores and Canary Islands), is mild and wet in winter, while becoming hot and muggy in summer. 


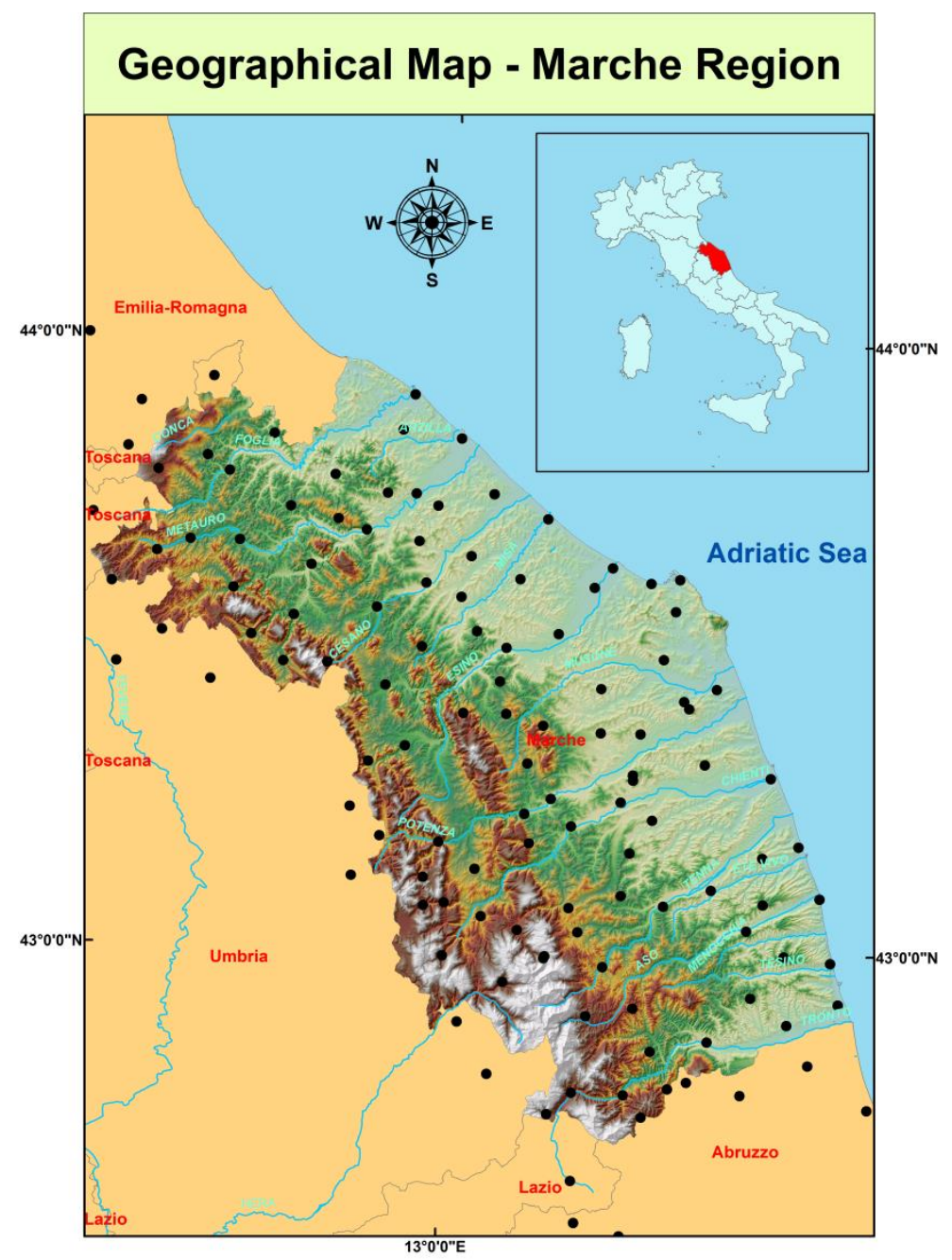

Fig. 1.Geographic map of the Marche Region; the 111 rain gauges taken into account are marked by circles.

\section{State of the Art}

Climate analyses are usually focused on standard themes, such as extreme monthly precipitation [Gutowski et al., 2008; Wang and Zhou, 2012], which has a great importance because of an increased frequency of occurrence of natural disasters; the relationship between global warming and changes in precipitation [Chou et al., 2009; Trenberth, 2011]; the probabilities of precipitation changes [Jones et 
al., 1994; Tebaldi et al., 2004] and in order to provide predictions for the future climate scenarios, and precipitation analysis [Serrano et al. 1999; Partal and Khaya, 2006] applied to other fields of interest (e.g. geomorphology, hydrogeology, ecology).

Spatial and temporal distributions of precipitation over central Italy during the last century have shown a moderate, irregular reduction of annual and seasonal rates equating to a precipitation decrease between $5 \%$ and $10 \%$ during the $20^{\text {th }}$ Century [Brunetti et al. , 2000a, b; Brunetti et al., 2006a, b; Colombo et al., 2007]. Winter is the season characterized by a heavier reduction in rainfall over central Italy as a whole. However, only a few studies have taken into account the relationships between local features and precipitation to obtain a better interpolation of sparse data; most studies consider elevation as the only dependent variable at a regional scale [Brunsdon et al., 2001]. The scarcity of this type of investigations can be caused by local differences in rainfall, depending on the climatological and topographical conditions of the investigated region, which need a detailed analysis obtained throughGIS software.

Only a few analyses have been carried out on precipitation in the Marche Region and there is no recent work in this area. Some of these take into account the standard precipitation index or analyze the relation between precipitation and other geographic features in a graphical way [Bisci et al., 1994; Bisci et al., 1996; Rossetti et al., 1997 Bisci et al., 2001; Bisci et al., 2002; Fazzini et al., 2002]. Furthermore, there is a study that dealing with precipitation and altitude in order to observe the ratio, but show the result as example only for August and December from 1948 to 1981 [Bordi et al., 2001]. Some other studieshave to be considered as reports of historical climatic records [Biondi et al., 1991; Amici and Spina, 2002; Bisci and Fazzini, 2002].

The most recent report for the Marche Region is from Amici and Spina (2002), whose work summarizes the amount of precipitation in this area and highlights a trend of decreasing precipitation, due to climate change. However, there is an analysis for the standard precipitation index from 1948 to 1981, which takes into account the altitude in order to have a better interpolation of precipitation in the area [Bordi et al., 2001].

\section{Methods}

\subsection{Quality control}

Rainfall data were collected for 111 rain gauges located in the regional territory and in its neighbours (Fig.1) for 1961-2016. The dataset was submitted to a quality control test composed of two parts [Aguilar et al., 2003; World Meteorological Organization, WMO, 2011]: 
1. Gross error checking - all the digitization errors and the strongly anomalous values were removed from the "raw" data after an investigation, which highlighted any negative or the clearly wrong values (too high for each climatic zone in the world), with the "conditional formatting" $\left(\right.$ Microsoft $\left.^{\circledR} \operatorname{Excel}^{\odot}\right)$.

2. Internal consistency check - a threshold has been set (from 0 to $800 \mathrm{~mm}$ of rain per month, threshold that exceeds of about $100 \mathrm{~mm}$ the highest values recorded by a rain gauges in this area) through the data validation tool of Microsoft ${ }^{\circledR} \mathrm{Ex}-$ cel $^{\circ}$.

Furthermore, for each rain gauge only complete monthly records were taken into account and also the annual means were calculated when all the months were complete. At the end of this validation procedure, 1102 values have been deleted $(1.67 \%$ of the source data).

Finally, the Craddock test [Craddock, 1979] for the identification of inhomogeneity of the time series confirmed an acceptable homogeneity of the dataset, while the Mann-Kendall test [Salmi et al., 2013] showed, for all the monthly series, an absence of significance of their trend, with p-values around 0.05 and 0.10 .

\subsection{Climate analysis method}

In order to identify climate changes, the rainfall data set has been split into two different periods, from 1961 to 1990 and from 1991 to 2016. These two periods have been chosen because they represent different climatological standard normals.

The data were examined to see if there was a statistically significant difference in precipitation between the two periods. If so, climate change could be one possible explanation or other reasons, such as temporary fluctuations, might be plausible.

This led to the construction of a multivariate model adopting several geographical and topographic features as independent variables influencing precipitation.

Thus it was possible to identify the most important independent variables for the Marche Region through a multiple regression analysis. This analysis was chosen to consider many topographic parameters in one model. Furthermore a second order polynomial regression was chosen as this allows better results of fitting to be obtained compared to, for example, the standard OLS (ordinary least squares) regression. The presence of outliers was also investigated in the analysis: some rain gauges are named outliers if their data don't follow the most common ratio with the independent variables, but show an abnormal distance from other values.

The first technical operation to edit maps was to create a DEM (Digital Elevation Model). All the sheets of the CTR (Carta Tecnica Regionale - technical map of the Region; 1:10000 nominal scale, provided by the Marche Region local government as AutoCAD files) were merged, extracting all the features relevant to determine relief (such as contour lines, elevation points, hydrographic network) and using them, in addition to elevation data of all available weather stations, to create a TIN (Triangulated Irregular Network). The latter was then corrected and optimized, 
checking suspect elevation values and adding new elevation points and polylines taken from geographical and topographical maps after their georeferencing in the software, in order to provide a better representation for the morphology of the area. Finally, the resulting TIN has been transformed into a detailed raster DEM with a cell size of $15 \mathrm{~m}$ (Fig. 1). All the geographical and topographic variables adopted for the analyses were obtained starting from the Digital Elevation Model.

\section{Results and Discussion}

\subsection{Rainfall analysis}

The analysis of rainfall of Marche Region starts from the report of standard parameters preparatory for the central part of the research. The calculated mean precipitation is $943 \mathrm{~mm}$ for the first period (1961-1990) and $915 \mathrm{~mm}$ for the second one (1991-2016), even though there is a similar geographical distribution, observed graphically through the ArcGis tool "Cluster and outlier Analysis" that identifies statistically significant distributions in the rain gauge data, using the Anselin Local Moran's I statistic[Anselin, 1995]. Standard deviations highlight a higher dispersion of data for 1961-1990 (209.46) than for 1991-2016 (177.95). In order to improve the evaluation of precipitation, symmetric percentiles have been considered (Table 1); $50 \%$ of the data ranges between $791 \mathrm{~mm}$ and $1032 \mathrm{~mm}$ for the period 1961 1990, while it ranges from $785 \mathrm{~mm}$ to $1018 \mathrm{~mm}$ for the period 1991-2016.

Figures 2 and 3, created using the "Geostatistical analyst" extension of $\mathrm{ArcGis}^{\odot}$ and selecting an IDW (Inverse Distance Weighted) method [Johnston et al., 2001; Wong and Lee, 2005], depict the distribution of precipitation in the study area for the two periods (1961-1990; 1991-2016). The IDW has been optimized finding the optimal power (control the weight of the measured values in relation to the distance, in the interpolation) for both periods. In fact the power that minimizes the root mean square error was chosen for the interpolation, through a cross validation that removes each data location one at a time and predict the value in the same location:

$$
\widehat{Z}\left(s_{0}\right)=\sum_{i=1}^{N} \lambda_{i} Z\left(s_{i}\right)
$$

where $\hat{Z}\left(s_{0}\right)$ is the value predicting for $s_{0}$ location; $N$ is the number of measured values; $\lambda_{i}$ are the weights; $Z\left(s_{i}\right)$ is the observed value at $s_{i}$ location. The comparison of Figs 2 and 3 highlights the differences between the two periods, in which there is a clear reduction of precipitation from 1961-1990 to 1991-2016. 


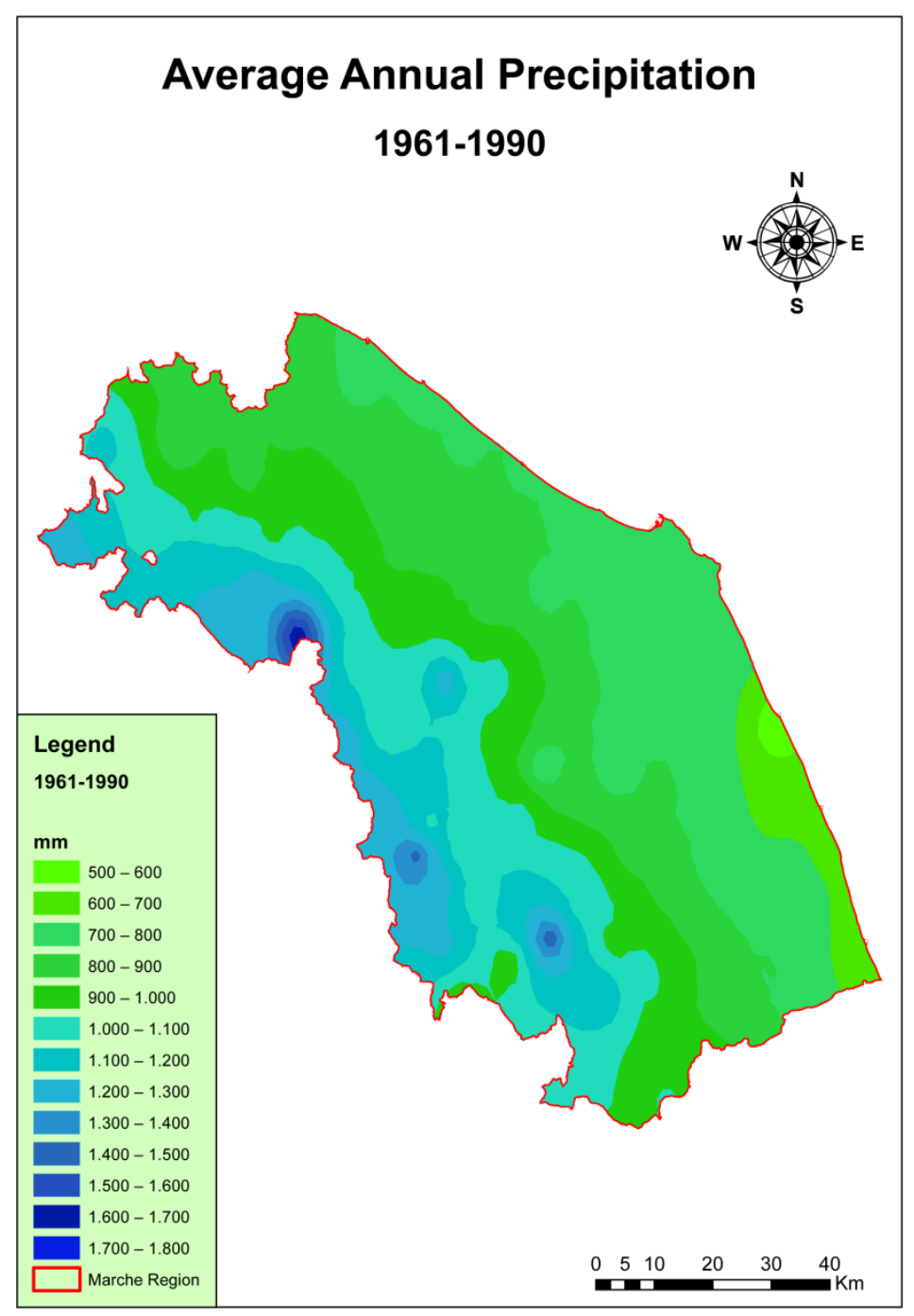

Fig. 2.Average annual precipitation 1961-1990. 


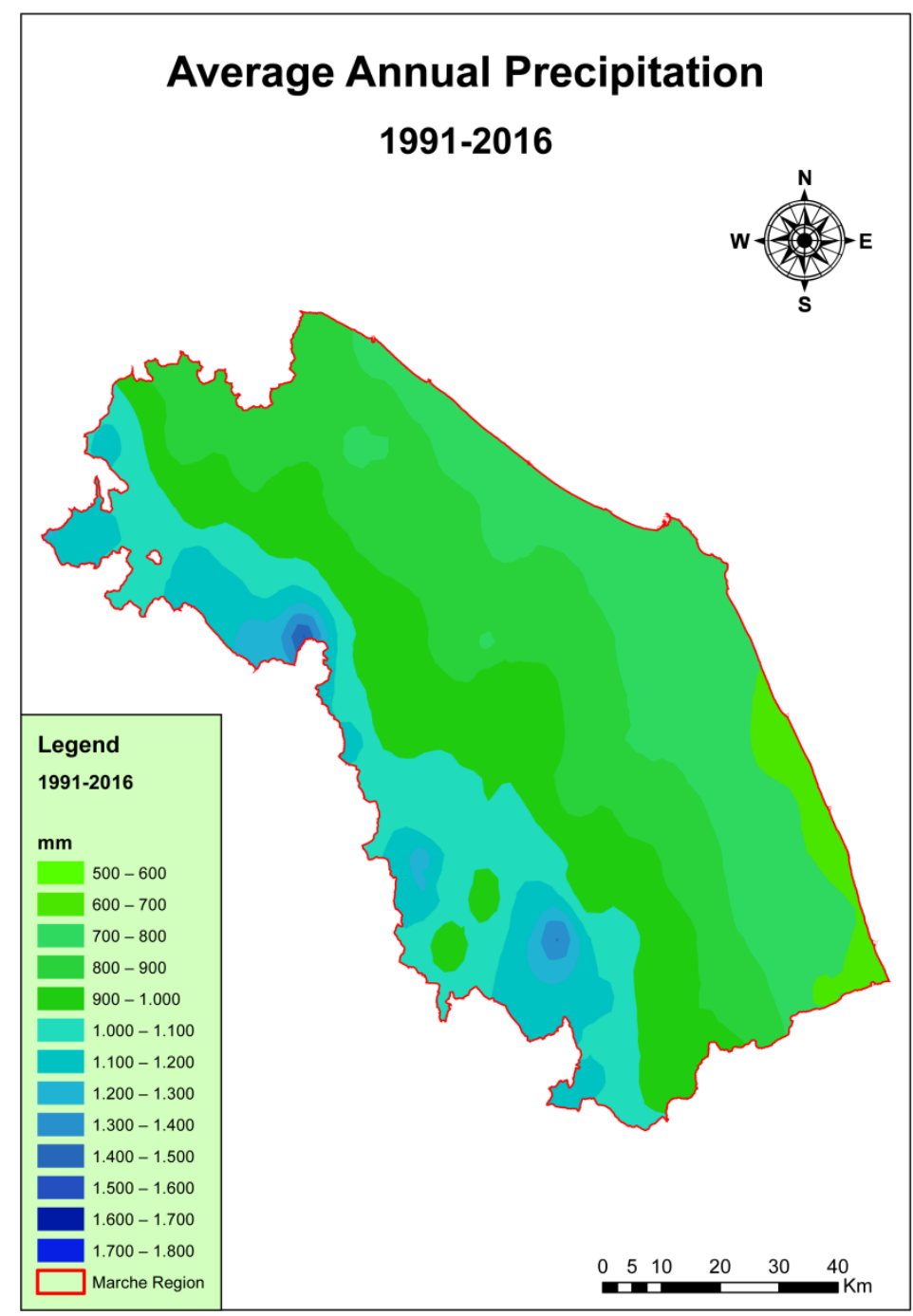

Fig. 3.Average annual precipitation 1991-2016.

\subsection{Regression analysis}

In the Marche Region in winter the Adriatic Sea is too small to mitigate the climate in a sensitive manner, as happens on the western coast with the Tyrrhenian Sea and the Atlantic Ocean. In fact the Apennines impede the free circulation of mild western air masses from Atlantic Ocean. This situation allows the incursion of air from the east and north-east, especially in winter, while continental tropical warm air is present predominantly present in summer. It is therefore necessary to 
highlight the importance of geography for the climate variability of this region that stretches gradually from the sea to the mountains. In fact, if the atmospheric circulation is the same for all the territory under investigation, both for large and small scale, then geography becomes a determining factor.

Multiple regressions have been calculated using six independent variables that could have a relation with rainfall: elevation, latitude, distance from the sea, slope angle, aspect, distance from rivers, distance from the main divide and local relief (i.e. difference of elevation between local divide and valley bottom) (Table 1). These variables are important because they are related to the climatic dynamics of this study area [Basist et al., 1994].

The first step in the regression analysis was to relate rainfall with all the variables, in order to estimate the best variable to use as the first parameter of regression. Data were analyzed using scatter plots, where the $y$-axis reports the dependent variable (rainfall) and the $\mathrm{x}$-axis the independent one (from the six geographic or topographic parameters). For each of those scatter graphs, the best fitting polynomial curve of the second order $\left(y=a^{2}+b x+c\right)$ was calculated, as well as the co-efficient of determination $\mathrm{R}^{2}$ obtained. A polynomial curve of second order was chosen because it fitted the data better than a line and the improvement of $R^{2}$ is negligible increasing the order. The whole process was required to find a model that could explain the analyzed data. Fig. 4, where the $\mathrm{x}$-axis represents the distance from the sea, shows an example of good fitting.

The representation by scatter graphs also allows assessment of the presence of outliers (stations showing anomalous values), related to particular environments or atmospheric dynamics [Alexander et al., 2008; Hijmans et al., 2008; Van den Brink and Können, 2008]. In Fig.4 two outliers are present (Bolognola and Fonte Avellana), showing a precipitation significantly higher than it could have been hypothesized; it is evident that the improvement of the fitting curve without the outliers in the second, where the co-efficient of determination (is a ratio between data variability and correctness of the model) increases from 0.64 to 0.73 . 


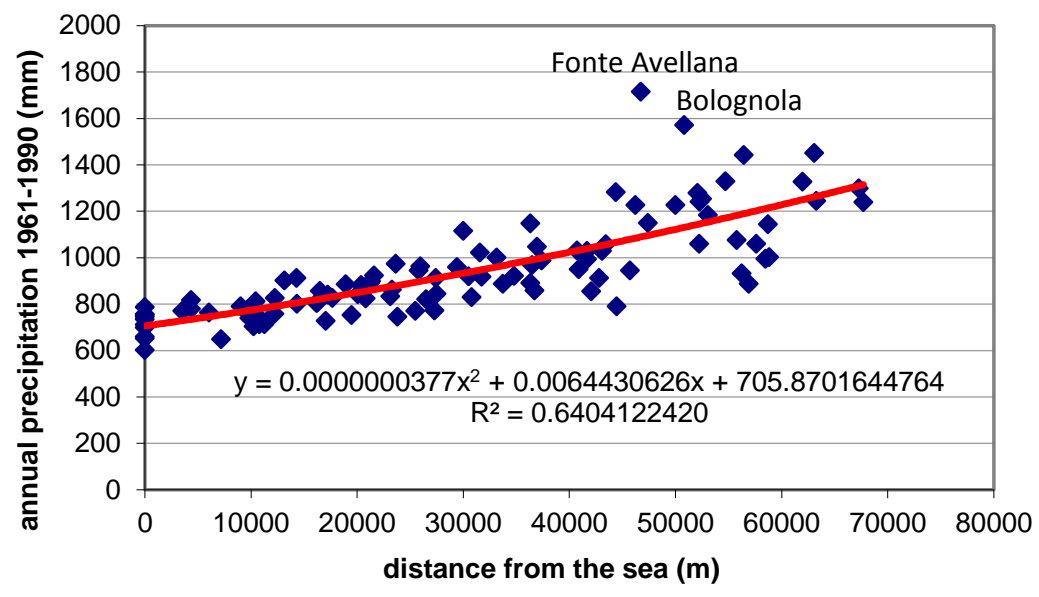

Fig. 4.- relationship between average annual precipitation 1961-1990 and distance from the sea.

Based on this first level of regression, for each environmental parameter and for each period, the expected rainfall has been calculated using the resulting polynomial equation: this value has then been subtracted from the recorded value to obtain the residual unexplained value. The analysis then continues through the comparison of residuals with the environmental features left, thus individuating the second best fitting independent variable, once more on the basis of the best coefficient of determination: continuing in this way, it was possible to calculate further new residuals and individuate independent variables, until the end of the procedure.

There are five levels in this analysis and the value of the coefficient of determination at the end of each level of regression, is added to the previous value of $\mathrm{R}^{2}$, up to the final value that represents the amount of weather comprehension by the model.

The following is a practical example of a complete regression, in this case for the period 1991-2016 and the annual average:

first parameter of regression (distance from the sea): $\mathrm{R}^{2}=0.625$

second parameter of regression (latitude): $\mathrm{R}^{2}=0.041$

third parameter of regression (altitude): $\mathrm{R}^{2}=0.038$

fourth parameter of regression (distance from the river): $\mathrm{R}^{2}=0.012$

fifth parameter of regression (local relief): $\mathrm{R}^{2}=0.010$

TOTAL: $\mathrm{R}^{2}=0.728$

At the end of multiple regression analysis, it is useful to make a summary with percentage of comprehension of data that express the relation between the dependent variable (precipitation) and the independent variables (distance from the sea, latitude, elevation) (Table1) to evaluate the best for each time series period and interval of time. 
Table 1 - List of the adopted independent variables.

\begin{tabular}{|c|c|c|c|c|c|c|}
\hline \multirow[t]{5}{*}{ Time interval } & $\begin{array}{l}\text { Independent varia- } \\
\text { bles }\end{array}$ & & & & & \\
\hline & First & Second & Third & Fourth & Fifth & \\
\hline & Year & $\begin{array}{l}\text { Distance } \\
\text { from sea }\end{array}$ & Latitude & $\begin{array}{l}\text { Local re- } \\
\text { lief }\end{array}$ & Elevation & $\begin{array}{l}\text { Distance from } \\
\text { divide }\end{array}$ \\
\hline & Spring & $\begin{array}{l}\text { Distance } \\
\text { from sea }\end{array}$ & $\begin{array}{l}\text { Local re- } \\
\text { lief }\end{array}$ & Latitude & Elevation & Distance river \\
\hline & Summer & $\begin{array}{l}\text { Distance } \\
\text { from sea }\end{array}$ & Latitude & Elevation & $\begin{array}{l}\text { Distance } \\
\text { river }\end{array}$ & $\begin{array}{l}\text { Distance from } \\
\text { divide }\end{array}$ \\
\hline \multirow{5}{*}{$\frac{\stackrel{\circ}{\frac{1}{1}}}{\frac{1}{\circ}}$} & Autumn & $\begin{array}{l}\text { Distance } \\
\text { from sea }\end{array}$ & $\begin{array}{l}\text { Local re- } \\
\text { lief }\end{array}$ & Latitude & Elevation & Distance river \\
\hline & Winter & $\begin{array}{l}\text { Distance } \\
\text { from sea }\end{array}$ & $\begin{array}{l}\text { Local re- } \\
\text { lief }\end{array}$ & Elevation & Elevation & $\begin{array}{l}\text { Distance from } \\
\text { divide }\end{array}$ \\
\hline & Year & $\begin{array}{l}\text { Distance } \\
\text { from sea }\end{array}$ & Latitude & Elevation & $\begin{array}{l}\text { Distance } \\
\text { river }\end{array}$ & Local relief \\
\hline & Spring & $\begin{array}{l}\text { Distance } \\
\text { from sea }\end{array}$ & Elevation & $\begin{array}{l}\text { Distance } \\
\text { river }\end{array}$ & Latitude & Local relief \\
\hline & Summer & $\begin{array}{l}\text { Distance } \\
\text { from sea }\end{array}$ & Elevation & Latitude & Local relief & Distance river \\
\hline \multirow{2}{*}{ 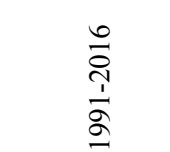 } & Autumn & $\begin{array}{l}\text { Distance } \\
\text { from sea }\end{array}$ & Latitude & Elevation & $\begin{array}{l}\text { Distance } \\
\text { river }\end{array}$ & Local relief \\
\hline & Winter & $\begin{array}{l}\text { Distance } \\
\text { from sea }\end{array}$ & $\begin{array}{l}\text { Local re- } \\
\text { lief }\end{array}$ & Latitude & Elevation & Distance river \\
\hline
\end{tabular}

It is shown that there is a noteworthy increase of the co-efficient of determination when outliers are excluded from calculations: the increase for the period 1961-1990 is higher than in the last one and it reaches values of greater reliability (from 3.7\% in summer to $11.4 \%$ in autumn) (Table 2). 
Table 2 - Percentage of variance explained by the regression.

\begin{tabular}{lll}
\hline & $1961-1990$ & $1991-2016$ \\
\hline All stations & & \\
Year & $74.3 \%$ & $72.8 \%$ \\
Spring & $70.1 \%$ & $70.6 \%$ \\
Summer & $62.2 \%$ & $45.8 \%$ \\
Autumn & $66.4 \%$ & $74.5 \%$ \\
Winter & $77.0 \%$ & $71.3 \%$ \\
Without outliers & & \\
Year & $81.7 \%$ & $75.2 \%$ \\
Spring & $78.5 \%$ & $72.8 \%$ \\
Summer & $65.9 \%$ & $45.7 \%$ \\
Autumn & $77.8 \%$ & $75.8 \%$ \\
Winter & $84.6 \%$ & $74.0 \%$ \\
\hline
\end{tabular}

Fig. 5 and Fig. 6 describe the differences between real and predicted values for the average annual rainfall during the periods: 1961-1990 (Fig. 5), 1991-2016 (Fig.6). 


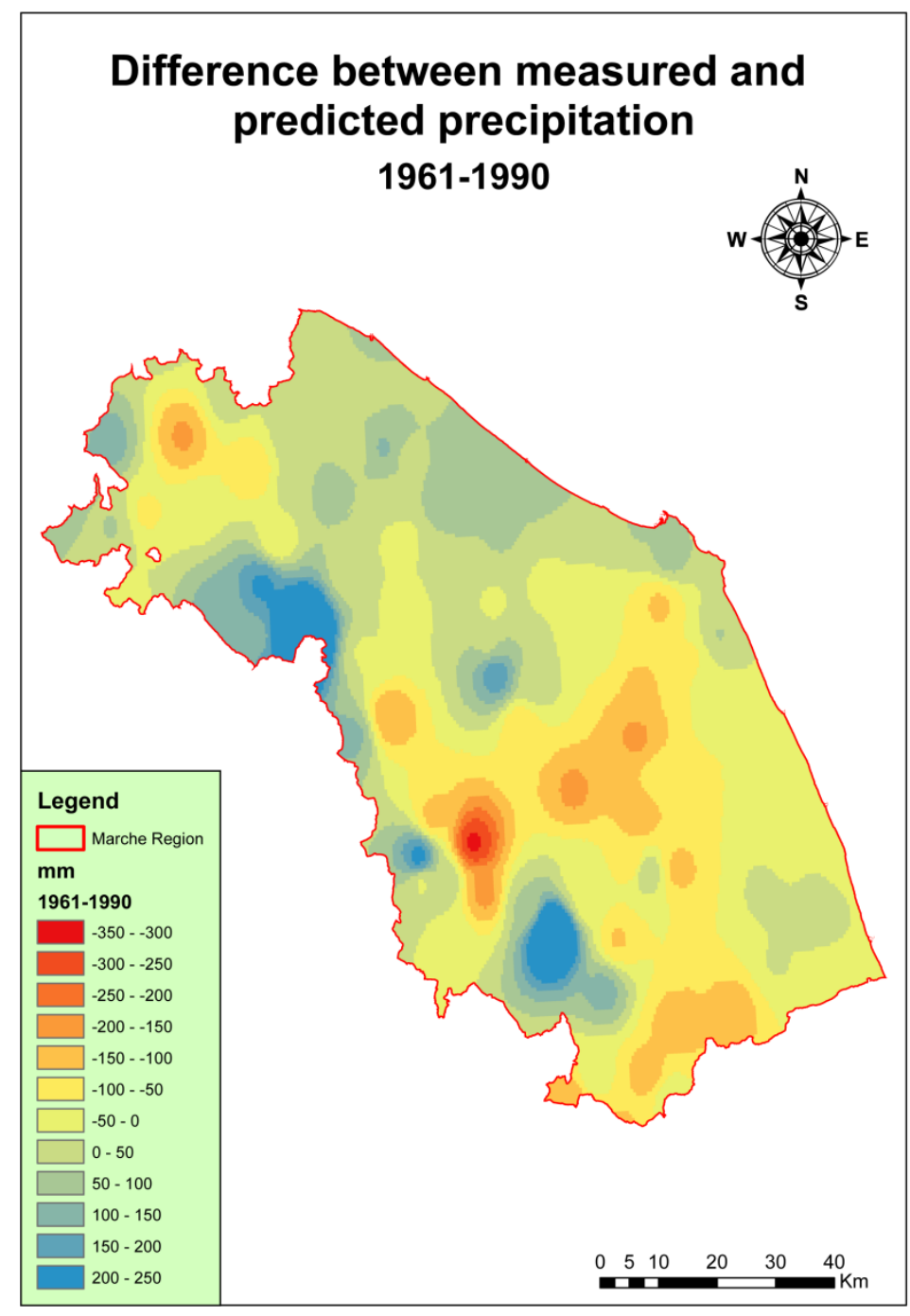

Fig. 5.Map of difference between predicted and observed valuesin 1961-1990. 


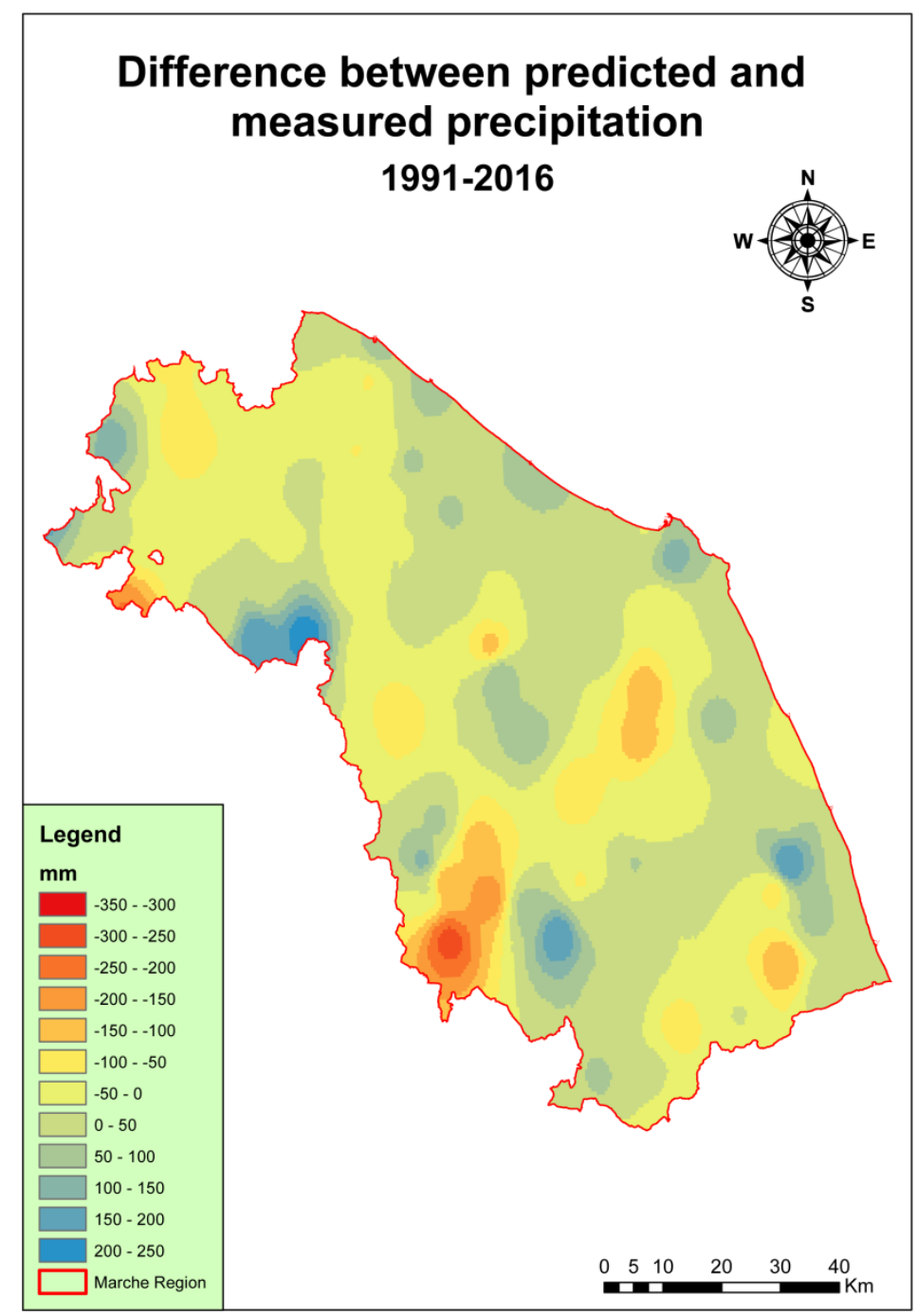

Fig. 6. Map of difference between predicted and observed values in 1991-2016.

Predicted values have been calculated on the basis of the resulting model from the 5 levels of regression analysis, while the real values are the measured ones. For both maps the best results have been obtained for the low elevation sector close to the Adriatic coast, while the highest differences (both positive and negative) are located close to the Apennines Range. In particular, there is a strong overestimation in the inner part of the province of Macerata (Centre-West part of the Region), while in the north-west part of the Region there is a substantial underestimation. The ratio between expected and real values is similar for both the adopted time intervals (Fig. 7). To assess the differences in a map between the models of the two periods, a raster subtraction (1961/1990-1991-2016) has been performed. Fig. 7 shows that 
there is a higher difference especially in those area affected by outliers $(300 / 350 \mathrm{~mm}$ of negative difference and 250/200mm of positive).

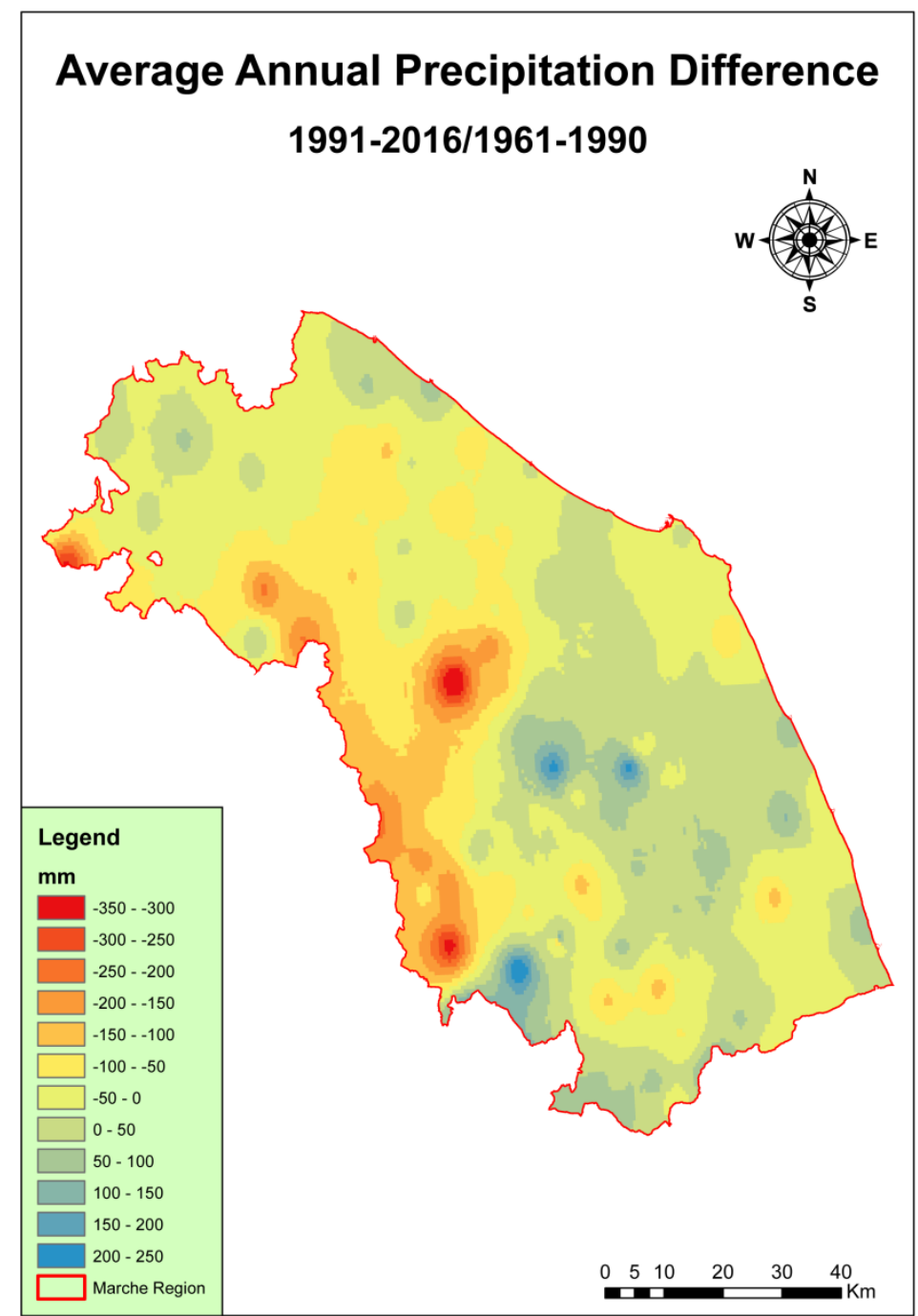

Fig. 7. Map of model performance, subtraction between the differences real predicted values 1991-2016 and 1961-1990.

The outliers highlighted more frequently during this analysis are the values for Fonte Avellana and Bolognola.

From the study it is evident that rainfall increases moving westward from the coast to the mountain range for both periods investigated, even if this relationship can be due prevailing to the topography of the Marche Region eastward from the 
Apennines and exposed to the same air masses. The minimum precipitation is always recorded in the coastal and hilly area located in the south-central part of the Region. During spring, this dry zone widens up to Ancona in the Central part of the regional coast. However, these results are affected by a strong underestimation of precipitation for the mountain rain gauges, probably due to the strong winds which don't allow a correct measurement of rainfall [Crisciotti and Preziosi, 1996; Andermann et al., 2001]. This problem is further amplified by the scarcity of rain gauges located above $1000 \mathrm{~m}$ (only three) and the absence of reliable gauges above 1400 $\mathrm{m}$ (this latter problem obliged an extrapolation of values at higher altitudes, with severe reduction of precision and reliability). This lack of reliable data in the Apennine Mountains probably leads to the creation of the outliers highlighted above. In fact it is a possible explanation of the strongest outliers detected in the graphs through the observation of their topographical features or the analysis of atmospheric dynamics.

Fonte Avellana is located at an elevation of $689 \mathrm{~m}$ along the eastern slope of high relief connected to the main watershed (Acuto Mountain, $1475 \mathrm{~m}$ ). In instances of advection air masses coming from the east it is affected by an intense stau effect (cold air build-up on the windward side of the mountain); therefore, the model underestimates precipitation by up to $27 \%$.

Rainfall at Bolognola is underestimated despite its high altitude $(1070 \mathrm{~m})$, because it is relatively close to the sea (around $50.8 \mathrm{~km}$ ) and has a high mountain range to the west. It is the only one of the measurement stations in the Marche Region to be affected by both the meteorological effects of the passage of Atlantic disturbances and Mediterranean ones, when linked to cyclogenes is over the Balkans, the lower Tyrrhenian (Ponza Low) or over the Ionian Sea.

Some further rain gauges behave as outliers only in one particular season: this is caused by local dynamics, often caused by topographical reasons, that in some seasons can represent a cover for the prevailing air masses.

The elimination of the major outliers has led to an improved understanding of precipitation in the Region, above all in the period 1961-1990. In fact, in this time the value of the total $\mathrm{R}^{2}$ changes from 0.743 to 0.818 , compared with 1991-2016 in which the coefficient of determination increases from 0.728 to 0.752 .

This may imply that interpolation gives better results with longer time series and highlights the great influence of the anomalous rain gauges on the result of the model.

\section{Conclusions}

This analysis can be considered an innovation because take into account many topographic parameters for each period, in order to choose those which fit better the precipitation data. The results achieved can be summarized in 3 main points: 
1. Precipitation decreases moving eastward, with a minimum to the south-east. This trend is in accordance with topography (it seems to be plausible that itcan cause orographic precipitations proportional to local elevation, that produce a result of $\mathrm{R}^{2}$ as first independent variable slightly less high than distance from the sea) and distance from the sea (a value of about 0.6 as $\mathrm{R}^{2}$ for both period probably due to the mitigation effect increasing close to the coast).

2. A downward trend for precipitation (of about $80 \mathrm{~mm}$ ) in the last period has been detected, except for in autumn (when precipitation remains constant)and summer (which showed a highly unpredictable behaviour without any prevailing trend: it can be assumed that rainfall may derive both from cold oceanic air advection and from ascending currents caused by surface warming resulting in local short but heavy thunderstorms). There is a significant decrease of rainfall from 1961-1990 to 1991-2016 in the hilly and mountainous sectors $(100-200 \mathrm{~mm})$, while in the area close to the coast the difference is slight (about $0-100 \mathrm{~mm}$ ).

3. Outliers of rainfall amount have been identified and interpreted. For a better explanation of their behaviour, an analysis of the seasonal distribution of wind direction is needed, but wind records are scarce and too poorly distributed in the area to accomplish such a task. It would be interesting to know also the trend of temperature in relation to precipitation, as well as solar radiation and air moisture, since all these parameters together could generate a complex model that could significantly improve the comprehension of outliers. Unfortunately, once more only a few recording stations furnish these observations.

The good continuity of rainfall data has allowed greater comprehension of rainfall space distribution and variation in the Marche Region than previously. This can constitute a relevant step toward the creation of a complete climate model that, in turn, may lead to an even more accurate interpolation and to a better explanation and characterization of outliers. Furthermore this study could be a tool to investigate slope stability, as well as both to characterize water reserves and to carry out agrometeorological studies.

The scarcity of recording stations in the mountain sector severely limits the accuracy of interpolation at elevations higher than $1000 \mathrm{~m}$. In the future this limitation will be less relevant, since some more rain gauges have been installed in the Sibillini Mountains starting from year 2000 at altitudes ranging between 1400 and $1900 \mathrm{~m}$.

Finally, in future it would be interesting to test geostatistical methods such as cokriging that could give good results with topographic variables reducing the estimation errors.

\section{References}

Aguilar E, Auer I, Brunet M, Peterson TC, WieringaJ (2003) Guidelines on Climate Metadata and Homogenization, WMO/TD No. 1186, WCDMP No.53; WMO: Geneve, CH. 
Alexander LV, Zhang X, Peterson TC, Caesar J, Gleason B, Klein Tank AMG, Griffiths G (2006) Global observed changes in daily climate extremes of temperature and precipitation. JGeophys Res, 111.doi: 10.1029/2005JD006290.

Amici M, Spina R (2002) Campo medio della precipitazione annuale e stagionale sulle Marche per il periodo 1950-2000. Centro di Ecologia e Climatologia - Osservatorio Geofisico Sperimentale: Macerata, IT.

Andermann C, Bonnet S, Gloaguen R (2001) Evaluation of precipitation data sets along Himalayan front.Geochemistry, Geophysics, Geosystems.

Anselin, L. (1995), Local Indicators of Spatial Association - LISA. Geographical Analysis, 27: 93-115. doi:10.1111/j.1538-4632.1995.tb00338.x.

Basist A, Bell G D, Meentemeyer V (1994) Statistical Relationships between Topography and Precipitation Patterns.J of Clim. 7:1305-1315.

Biondi E, Baldoni MA, Talamonti MC (1991) Il fitoclima delle Marche. Atti Conv. Salvaguardia e Gestione dei Beni ambientali nelle Marche, Ancona, IT.

Bisci C, Dramis F, Fazzini M, AltobelloL, Dorigato S (2001) Analyse des trends termo-pluviometriques du versant Adriatique compris entre la lagune de Venice et le Cap de Santa Maria di Leuca (Italie orientale). Climat et environnement : Actes XIV Congr. Ass. Intern. Climatologie, Seville, ESP.

Bisci C, Farabollini P, Fazzini M, FolchiVici C, Viglione F (1996) Variations récents des précipitations en la Région Marche (Italie Centrale). Coll. Assoc. Intern. deClimatologie, Strasbourg, FR.

Bisci C,Fazzini M (2002) Climatic features of the central southern Marches (Central Italy). Proc. "Natural hazard on built-up areas" CERG - Camerino, 45-47.

Bisci C, Fazzini M, Coccia N (2002) Analyse spatio-temporelle des séries des températures dans l'Apennin centre-méridionale italien par rapport aux paramètres topo-géographiques. Applications de la climatologie aux echelles fines, Actes XV Congr. Ass. Intern. Climatologie, Besançon, FR.

Bisci C, Fazzini M, FolchiVici C,Viglione F (1994) Multivariateanalysis of time trend of rainfall in the Marche area (Central Italy). I.G.U. Comm. on Climatology, Contemporary Climatology, Brno, $\mathrm{CZ}$

Bordi I, Frigio S, Parenti P, Speranza A,Sutera A (2001) The analysis of the Standardized Precipitation Index in the Mediterranean area: regional patterns. Ann. Geof., 44, 979-993.

Brunetti M, Buffoni L, Mangianti F, Maugeri M, Nanni T (2006) Temperature, precipitation and extreme events during the last century in Italy. Glob Planet Change, 40, 141-149.

Brunetti M, Maugeri M,NanniT (2000a) Variations of temperature and precipitation in Italy from 1866 to 1995 . TheorApplClimatol., 65, 165-174.

Brunetti M, Maugeri M,Nanni T (2000b) Trends of minimum and maximum daily temperatures in Italy from 1865 to 1996. Theor. Appl. Climatol., 66, 49-60.

Brunetti M, Maugeri M, Monti F,Nanni T (2006) Temperature and precipitation variability in Italy in the last two centuries from homogenised instrumental time series. Int. J. Climatol., 26, 345381, doi: 10.1002/joc. 1251 .

Brunsdon C, McClatchey J, Unwin DJ (2001) Spatial variations in the average rainfall-altitude relationship in Great Britain: an approach using geographically weighted regression. Int. J. Climatol., 21, doi: 10.1002/joc.614.

Chou C, Neelin JD, Chen CA, Tu JY (2009) Evaluating the "Rich-Get-Richer" Mechanism in Tropical Precipitation Change under Global Warming. J. Clim., 22, 1982-2005.doi: http://dx.doi.org/10.1175/2008JCLI2471.1.

Colombo T, Pelino V, Vergari S,CristofanelliP, Bonasoni P (2007) Study of temperature and precipitation variations in Italy based on surface instrumental observations. Glob. Planet. Change, $57.3,308-318$.

Craddock JM (1979) Methods of comparing annual rainfall records for climatic porposes. Weather 34. 
Crisciotti C, Preziosi E (1996) Analisi della variabilità spaziale della precipitazione nel bacino del Fiume Nera (Italia centrale): primi risultati. V Conv. Naz. Giovani Ricercatori in Geologia Applicata, Cagliari, IT.

Fazzini M, Bisci C, Dramis F, Altobello L, Dorigato S, Fubelli G, Molin P (2002) Statistic analisys of thermometric and pluviometric trends along the Adriatic side of the Italian peninsula. Proc. IAG Intern. Symp., Addis Ababa, ETH.

Geiger R (1954) Landolt-Börnstein - Zahlenwerte und FunktionenausPhysik, Chemie, Astronomie, Geophysik und Technik. alteSerie Vol. 3, Ch. Klassifikation der Klimatenach W. Köppen, Springer, 603-607.

Gutowski WJJR, Raymond WA, Kawazoe S, Flory DM,Takle ES, Biner S,Snyder MA (2008) Regional Extreme Monthly Precipitation Simulated by NARCCAP RCMs. J. of Hydrometeor., 11 .

Hijmans RJ, Susan E, Cameron SE, Parra JL, Jones PG, Jarvis A (2008) Very High Resolution Interpolated Climate Surfaces For Global Land Areas. Int. J. Climatol., 25, 1965 1978.doi:10.1002/joc.1276.

Johnston K, VerHoefJM, Krivoruchko K, Lucas N (2001) Using ArcGis Geostatistical Analyst. ESRI: Redlands, USA.

Jones RG, Murphy JM, Noguer M, (1995) Simulation of climate change over europe using a nested regional-climate model. I: Assessment of control climate, including sensitivity to location of lateral boundaries. Q.J.R. Meteorol. Soc., 121, 1413-1449. doi: 10.1002/qj.49712152610.

KöppenW, (1900) VersucheinerKlassifikation der Klimate, vorzugsweisenachihren Beziehungenzur Pflanzenwelt. Geogr.Zeitschr., 6, 593-611, 657-679.

Partal T, Kahya E (2006) Trend analysis in Turkish precipitation data.Hydrol. Process., 20, $2011-$ 2026.doi:http://dx.doi.org/10.1002/hyp.5993.

Rossetti R., Bisci C, Dramis F, Fazzini M, Speranza A, (1997) Etude de la distribution des precipitations en fonction des caracteres geographiques et morphometriques de la règion Marche (Italie centrale, cote adriatique). Coll. Assoc. Intern. de Climatologie, Quebec, CAN.

Salmi T, Määttä A, Pia Anttila, Amnell T, (2013) Makesens 1.0.xls, Meteorological Finnish Institute.

Serrano A, Matos VL, Garcia JA (1999) Trend analysis of monthly precipitation over the iberian peninsula for the period 1921-1995, Phys Chem Earth Pt B.,24, 85-90.

Spina R, Stortini S, Fusari R, Scuterini C, Di Marino M (2002) Caratterizzazione climatologica delle Marche: campo medio della temperatura per il periodo 1950-200. Centro di Ecologia e Climatologia - Osservatorio Geofisico Sperimentale, Macerata, IT.

Tebaldi CL, Mearns O, Nychka D, Smith RL (2004) Regional probabilities of precipitation change: A Bayesian analysis of multimodel simulations. Geophys.Res., 31.doi:10.1029/2004GL021276.

Trenberth KE (2011) Changes in precipitation with climate change. Clim. Res., 47, 123-138.doi: $10.3354 / \mathrm{cr} 00953$.

Van den Brink HW,Können GP (2008) The statistical distribution of meteorological outliers. Geophys.Res., 35.doi:10.1029/2008GL035967.

Wang Y, Zhou L (2005) Observed trends in extreme precipitation events in China during 19612001 and the associated changes in large-scale circulation, Geophys. Res., 32.doi:10.1029/2005GL022574.

World Meteorological Organization. (2011) Guide to Climatological Practices. WMO No. 100, WMO: Geneve, $\mathrm{CH}$.

Wong WSD, Lee J (2005) Statistical analysis of geographic information with ArcView GIS and ArcGIS. Wiley: Hoboken, USA. 